\title{
RECOUNTING STORIES IN SOUTH AFRICAN CHILD WELFARE
}

\section{Jeanette Schmid}

\section{INTRODUCTION}

In order to proactively bring about change, it is critical in a post-apartheid context for South African social workers to appreciate how colonial and apartheid forces have shaped the inherited welfare priorities, structures, legislation, policies and practices. It is as necessary also to identify stories of resistance as these offer hope and alternative possibilities. Authors such as McKendrick (2001), Patel (2005) and Loffell (2000) have tracked many aspects of South African welfare history. In its submission to the Truth and Reconciliation Commission - a body set up to formally acknowledge past injustices with the goal of bringing about political reconciliation - the welfare sector set out how it had contributed to historical discrimination and wrongs (Truth and Reconciliation Commission, 1999). While these narratives provide the framework for the development of child welfare in South Africa, relatively little is known about its particular history, especially its earliest roots. Beukes and Gannon (1999) and Allsopp (2005) have attempted to explore the origins of that profession in the child and youth work field. Badroodien (2001) examined the extensive impact of one institution, the Ottery School of Industry, on "coloured" youths and their families. Scordillis and Becker (2005) recount briefly the history of adoption practice in South Africa. Some of the child welfare societies have been able to provide sketches of their agency history. In this article the author attempts to add to the child welfare record, gathering the existing strands of literature and inserting the stories that emerged in her doctoral research (Schmid, 2008b).

As part of her doctoral studies, which were concluded in 2008, the researcher reviewed almost 200 documents up to 2007 pertaining to South African child welfare (including government policies and agency materials), examining in particular those of six child welfare agencies representing urban and rural contexts as well as established and neophyte organisations. These agencies are described as Agency 1 to Agency 6. This paper reflects the archaeological aspect of the genealogy investigated (Foucault, 1972), thus naming particular historical trends, but not interpreting them in terms of interruptions and continuities reflected in the present.

What we know as history is always a construction by those who recount the stories; in other words, it is shaped by the story-teller's context and worldview (Alvesson \& Skoldberg, 2000). Foregrounded discourses eclipse other vital narratives. Both dominant and marginalised stories need to be recorded. Since the demise of apartheid social work practitioners have been concerned about how past efforts have been interpreted, wanting a validation of the positive aspects of historical welfare interventions in addition to the critiques of how welfare work intentionally and unintentionally supported the colonial and later apartheid agendas (Patel, Schmid \& Hochfeld, 2012). This author hopes to provide a critical overview of both narratives, raising questions about some of the yet untold stories of South African child welfare. 
The broad historical developments in the field of child welfare are first summarised. The author then relates the history of the National Council (now known as Child Welfare South Africa) and provides a summary of the developments within the six child welfare agencies that were studied. The article concludes by considering the central threads emerging from these narratives.

\section{AN OVERVIEW OF HISTORICAL DEVELOPMENTS}

\section{Colonial beginnings}

The literature suggests that the history of South African child welfare, like welfare more broadly, has its roots in the colonial project. The first Dutch settlement was established in the Cape in 1652. "White" children and adults in need were placed with more well-off families who received monthly compensation from the Dutch East India Company (Beukes \& Gannon, 1999). The seeds of a child protection sensibility were sown when the first children's home was established in the Cape Colony as early as 1814, catering specifically for orphans. Institutions for young offenders were established after the introduction of the Verbeterinrichtingen Wet (Reform Schools Act) in 1819 (Beukes \& Gannon, 1999). Despite the British abolishing slavery in the colony in 1807, the emancipation of slaves was realised only in 1834 (Simons \& Simons, 1969). Indeed, proclamations in 1812 and 1819 permitted settlers to employ without compensation "coloured" girls between the ages of 8-18 years who had been orphaned, destitute or raised on the employer's property (Simons \& Simons, 1969). Beukes and Gannon (1997) report that the Meesters en Diensboden Wet (Masters and Servants Act) of 1856 placed neglected children in substitute families. It is difficult to ascertain how benign this Act was regarding children, as its primary intent was to criminalise the breaching of employment contracts particularly by "coloured" and "African" workers (Magubane, 2001; Simons \& Simons, 1969). It is also difficult to determine whether the legislation passed later was intended only for the protection of 'white' children or whether these Acts were in fact aimed at children of all race groups. In 1895 two pieces of legislation were enacted: the Wet op Verlate Vroue en Kinderbescherming (Abandoned Women and Child Protection Act) under which fathers were made financially responsible for their families and the Verwaarloosde Kinderversorging Wet (Care of Neglected Children Act), which facilitated the placement of neglected children in apprenticeships and dealt more comprehensively with children's needs (Beukes \& Gannon, 1999). Similar legislation was passed in the other regions which later formed South Africa: the Orange Free State in 1893, Natal in 1901 and the Transvaal in 1903 (Beukes \& Gannon, 1999). These initiatives provided the context for the launch of the Cape Town Children Life Protection Society (later known as the Cape Town Child Welfare Society) in 1908 and

\footnotetext{
1 Formal racial classifications have dominated South African constructions of ethnicity, four primary groups being identified during the apartheid period, namely Africans, Coloureds (persons of mixed origins), Indians (persons with Indian heritage) and Whites. These terms are here used recognising their limitations.
} 
the Johannesburg Children's Aid Society (later known as the Johannesburg Child Welfare Society and now as Jo'burg Child Welfare), which were concerned with the high mortality rate of infants and the lack of shelters for deserted and neglected children (Child Welfare South Africa, 2005; Truth and Reconciliation Commission, 1999). A Child Welfare Congress was held in 1911 to facilitate liaison between the respective Societies (Beukes \& Gannon, 1999) and another in 1917. The Wet ter Bescherming van Kindern (Child Protection Act) of 1913 was the first national legislation introduced (after the formation of the Union in 1910) regarding children in need of care.

\section{The development of formal child welfare services}

The period that followed resulted in thirty-eight child welfare agencies being established around the country, leading to the formation of the South African National Council for Child Welfare in 1924 (later becoming the South African Council for Child and Family Welfare, and in 2004 Child Welfare South Africa). The majority of child welfare services were directed at 'white' children. However, other population groups were also served, though the provision of services tended to be inadequate (Schmid, 2008). Volunteers ran preventive health, medical and dental programmes for school-going children. They also placed in orphanages children perceived as being needy, neglected and ill-treated, removing them from the adverse conditions in which they had been found (Child Welfare South Africa, 2005). These origins are not unlike the beginnings of Anglo-American systems, where the members of the middle class saw themselves as rescuing poor children from immoral and degrading environments (Cameron, Freymond, Cornfield \& Palmer, 2001; Carniol, 2000). The work became professionalised and in the late 1930s the state began subsidising the salaries of social workers in approved posts.

In 1937 the Children's Act was passed, being replaced with a new Children's Act in 1960. This Act included provisions for state subsidisation of children's homes, places of safety and industrial schools (Beukes \& Gannon, 1996). In 1983 the Child Care Act was introduced. The Act was amended in 1996/7 to shift from the idea of the unfit parent to the child in need of care. The Children's Act of 2005 reflects child welfare legislation in the post-apartheid era (September, 2006).

\section{The apartheid influence}

The apartheid regime required services to be provided on the basis of race, enforcing racial segregation. Although challenges to the racially-based structure of child welfare services emerged from the late 1970s, with certain agencies refusing to work within this dispensation, opposition was limited and substantial, widespread change only began in the 1990s (Truth and Reconciliation Commission, 1999). Since the macro environment was extremely repressive and challenging, apartheid regulations could result in severe penalties for the organisation and the individuals involved - thus discouraging any overt political opposition - and the efforts made by these organisations to resist the dominant system by calling on the state to address the conditions of children under this state of repression were minimal in effect. Overall, the child welfare field complied with apartheid directives (Truth and Reconciliation Commission, 1999). Political initiatives, such as the Free the Children Alliance, highlighted the plight of children, children's 
rights being formally placed on the political agenda (Allsopp, 2005). South Africa became a signatory to the United Nations Convention on the Rights of the Child in 1997.

It does not appear from reviewing the foundations of South African child welfare that South Africa shares the colonial histories of countries such as Canada and Australia, where aboriginal children were actively removed from their homes and placed in settings where they would be re-acculturated to dominant values (Lonne, Parton \& Thomson, 2009). Rather, in South Africa the focus during both the colonial and apartheid eras was on segregation, with a concomitant lack, or under-provision, of services to the majority. Thus the legacy of apartheid was a largely fragmented and discriminatory welfare (and child welfare) system that was constructed to serve primarily "whites" in urban areas (Taback, 2001). It was residual in type and expertdriven. This system did little to address the needs of the poor. In a post-apartheid context it was clearly not feasible to continue offering welfare services within such an unjust framework, as equitable services were needed to reach all South Africans. Transformation became a significant priority.

The history above depicts the major milestones in the child welfare field. It is worth considering more explicitly the developments within the National Council and particular agencies, partly to introduce further texture to the overall history and partly because of the National Council's significant role both in child welfare and the broader welfare sector.

\section{AGENCY HISTORIES}

The author first describes the nature of the study and then outlines the history of the National Council; this is followed by the stories of the agencies examined.

\section{The study}

The genealogical study, conducted through a Foucauldian lens, was carried out in order to identify the dominant and hidden discourses in South African child welfare. The author purposefully selected a rural and an urban province, and then within these two provinces selected established and neophyte organisations. The history of the national council for child welfare was also examined to provide a context for understanding agency developments.

Two data-sourcing strategies were utilised. First, 187 documents (including "grey" materials such as annual reports, internal policy papers and reports to government) were analysed. The discourses reflected in government and agency documents were identified through content analysis that reflected dominant themes. Documents up to and including the year 2007 were examined. The qualitative approach allowed for a nuanced, textured description of the history of the organisations studied. Content analysis, however, is a subjective process, the views of the researcher almost inevitably colouring the findings. The small sample of agencies reviewed limited the inferences that could be made. As a second strategy, therefore, interviews with key child welfare figures were used as mechanisms to limit subjectivity and increase the reliability of the findings. Interviews were conducted with 10 key informants from agencies such as the Nelson Mandela 
Children's Fund, Child Line, UNICEF and the Children's Institute. Sampling was here also purposeful, interviews were unstructured, focusing on shifts in welfare service delivery. Content analysis was utilised to identify the prevailing themes raised by interviewees.

Despite the study limitations, dominant and minor discourses could be identified (Schmid, 2010, 2008b). In summary, a child protection discourse emerged as the major discourse. While developmental social work discourse influenced the language and rhetoric of agencies, it had not by 2007 fundamentally shifted practice.

The histories reflected in this paper are one (incidental) aspect of the overall study. The interview data are not reflected in this article, because shifts in the welfare discourse rather than the significance of particular historic events were the focus in the interviews.

\section{The National Council}

\section{Health and welfare concerns}

The National Council for Child and Family Welfare was established in 1924 with 38 member organizations. In 2008, as Child Welfare South Africa, it had expanded to more than 170 affiliates. The earliest record available to the researcher is the 1963 Annual Report, which deals with the liaison function of the Council. At that time the Council engaged in public relations, and offered social work and nursing consultation as well as "guidance" to its affiliated Societies. The issues that were discussed at the Council meeting are summarised as including "the extension of the Government scheme subsidising skimmed milk powder for the prevention of kwashiorkor"; "the care of children during the hospitalisation of mothers"; "free medical services to children" in foster care; finalising procedures around "detention orders" (regarding the apprehension of children); "the delay in foster care grants", "the insufficiency of public assistance", "the establishment of more places of safety and detention", "the increase of income ceilings" regarding subsidies for "white" crèches; "more homes for Coloured children"; "the increase of employment opportunities for the mentally and physically handicapped", and the "increase of custodial and day occupational training centre facilities for the scholastically uneducable". The committees that existed at this time persisted for years, namely Health, Nursing and Mothercraft, Adoptions, Social Work, and Non-white Child Welfare Work. In 1986 the re-named Professional Health Committee was finally disbanded, as it was concluded that its mandate had been picked up within paediatric health structures.

\section{Tensions regarding resource provision}

A theme regarding race and associated issues winds through the National Council documents. These statements generally reflect how tied the Council was to the apartheid regime (e.g. the Minister or Deputy of Social Welfare and Pensions traditionally opened council meetings, and the wife of the State President was at one time patron of the Council), but also that this connection created significant internal tensions. Thus, on the one hand, comments are made supporting the dominant agenda. On the other hand, concerns are raised about inequity and inadequacy of resource provision, and the place 
of 'non-white' members in the Council. The statements also reflect changing sensibilities on a macro level. The author presents the comments here as they arise in the documents.

As noted earlier, as of 1966, the state ordained that private welfare agencies (who took on the major part of statutory services) work within racial, religious, language and cultural boundaries. The government expected the National Council to be for "whites" only, who were to represent other population groups. The Council had already in 1963 established a "non-white" committee as required by Department of Bantu Administration and Development, as 'African' people (then referred to as "Bantu') had to work towards their own development themselves. In the 1963 report the 'non-white' committees lamented the "inadequate public assistance and state grants", "the lack of housing" and the shortage and inadequacy of "nursing and educational facilities". This became a consistent refrain over the years. For example, in 1970/2 and 1972/4 the "coloured", "Indian" and "African" committees of the National Council raised concerns about issues such as the lack of grants and their lack of parity; platoon systems at schools; long travelling times to schools; overcrowding and inadequate housing; and a lack of places of safety and children's homes. At the same time speakers at the National Council, while recognising disparities, did not assume responsibility and promoted racial stereotypes. For example, the Director of Education as the opening speaker to the National Council in 1968-70 asserted: "We need a policy to encourage education and direct a wider participation of the respective racial groups. Assistance should never breed parasites but should help people to help themselves." As highlighted in the Council minutes, in 1970 Advocate De Villiers noted:

"Diversity is a challenge. Reasonably adequate housing is important. White families are encouraged to have larger families but we don't have affordable housing for reasonably sized families. Among Coloured, Indian and Black families problems are created by families being too large. Reasonable control of population growth is a matter of elementary self-interest as well as of healthy inter-group relations. Probably the issue is one of convincing people directly that this is so, of overcoming suspicions, customs, traditions and other obstacles."

In the following years a greater sensitivity to the needs of race groups other than "whites" is evidenced, though this did not result in substantive change. Against the backdrop of the Soweto uprising in 1976, the National Council's "Indian" Division adjourned until a non-racial constitution was approved. This occurred six years later in 1982. A Council newsletter in 1977 reported that it would be substituting the word "African" for "Bantu". One article in the newsletter maintained that "child welfare was best placed to deal with race relations" because child welfare was in essence about mothers, who were assumed to be inherently "peacemakers". The "non-white" committees in 1976/8 demanded full participation in the decision making of the Council's affairs. Again, it was only in a 1981 newsletter that the National Council reported that it needed a new (non-racial) structure and constitution. It also noted, however, that child welfare personnel had visited the South African National Defence 
Force, a structure that embodied and literally defended apartheid. In 1980 the National Council proposed a unified children's court, rather than courts differentiated by race. The Council in 1986 issued a statement to the government that the State of Emergency undermined family life. It also called for the age limit on grants for "black" children to be increased from 16 to 18 years to allow children to stay at school, and to ensure that age limits on grants were consistent across all races.

In the 1990s the Council passed an affirmative action policy, including recommendations for the amalgamation and rationalisation of racially segregated services. A historic moment occurred in 1998 when the Council participated in writing the first NGO country report on the Status of South Africa's children. By 2007 the National Council was prioritising the development of affiliates in previously underserviced areas, primarily engaging community volunteers in either the Isolobantwana (identifying child abuse) and Asibavikele (identifying children affected by HIV and AIDS) programmes.

The pattern reflected in the National Council's historical progression is partly mirrored in the agencies' stories. The author provides thumbnail sketches of significant developments for each agency, as this provides some insight into the historical arc of South African child welfare agencies.

\section{Agency histories}

The first three agencies considered are located in an urban province. Agency 1, located in the city, was established in the early 1900s, providing protective substitute care services, medical and dental clinics, crèches and residential care. In 1930 an adoption home for unmarried mothers was built. The first township ${ }^{2}$ crèche was built in 1939. By 1948 the primary functions of the agency were running children's homes, managing crèches and doing casework. The maintenance grant function was handed to the state department in 1950. In 1952 there was a shift in the provision of residential care, with the adoption of a "cottage" approach. Another major re-orientation occurred in the mid1980s, when community work became a priority. In 1984 the agency supported the establishment of a shelter for street children and in 1990 launched a centre to prevent and treat sexual abuse. In 1991 the agency cautioned that AIDS would pose a major threat and introduced an AIDS policy. Because of a lack of funding, four of the five residential facilities were shut down in 2000, including a children's home in a township. By 2003 all the agency's services had been 'adjusted' to deal with HIV and AIDS, and a day-care centre for orphaned and vulnerable children opened with the support of international funding. However, the original crèches run by the agency were all being closed or handed over to the community, the last one closing in 2004. Capacity building of community-based organisations became a focus. The prevailing government agenda continued to directly influence the activities of agencies and the way that organisational programs are articulated. For example, in 2004/5 Agency 1 said its intent was

\footnotetext{
2 Townships in South African parlance refer to settlements outside of cities and towns, which under the apartheid era were reserved for those considered "non-white".
} 
“...to provide, support and monitor suitable alternative care for children in need of such care and to rehabilitate biological parents so that they can safely care for their own children. This is in line with the Constitution, children's rights and obviously addresses community needs and priorities such as HIV AND AIDS, poverty, child abuse, abandonment, orphanhood, alcohol and drug abuse, and a myriad of other causes of child neglect."

The next year Agency 1 reframed its work within the context of the Millennium Development Goals which were being advanced by the government as part of an international response to poverty in the so-called developing world.

Agency 2, also a city-based organisation was established at a similar time to its counterpart, Agency 1. It opened a children's home in 1928 and ten years later hired its first social worker. In 1939 a place of safety was established in a township, with services being provided in three townships by 1945. The agency hired its first 'black' social worker a year later. In 1955 Agency 2 developed a foster care specialisation. In 1960 the first intake social worker was appointed. The "Indian" community previously served by the organisation established a separate, independent child welfare agency in 1965. In 1968 under government direction the agency formed "Bantu" and "coloured" committees. This agency hired a community worker for the first time in 1974 and in this year first ran a group work programme. In 1980/1 the agency was offering both crèche and after-school facilities from its (white) residence. After-school centres were launched in two townships a year later. In contrast to Agency 1, it opened up a shelter for street children only in 1993, the same year the children's home was re-structured to a cottage system. In 1996 abortion counselling was offered, while five of its crèches were "privatised". An AIDS care centre was set up with private funding in 2001. In 2005 the agency changed its name in accordance with geographical name changes.

Agency 3, a township-based agency in the same province as the first two organisations, was founded as a crèche under the auspices of a city agency in 1945, becoming independent by 1967 when it comprised two crèches. In 1980 the agency finally received state funding and in 1985 a social work position was created. In 2000 the social work service was placed under the auspices of the original city agency, being moved to the National Council in 2003. Two social work offices were opened in 2006.

Three other agencies reviewed were all located in the same rural province. The histories of each are summarised below.

Agency 4, located in the city, was formed in the early 1920s. It employed a rural nurse and health visitor in 1931. In 1937 it was formally constituted, dividing into "white" and "non-white" committees in 1948. In the 1950s the "non-white" committee was instructed to establish itself separately from the organisation. In 1969 a social work post was first subsidised. In 1989 the services were extended once more to the entire magisterial district. In the 1990s a support group for day mothers was launched and a charity clothes store (identified as an income-generation programme) was set up. In 1996 a joint place of safety and shelter for abused women was created. In the early 2000s the language of developmental social welfare (the formal post-apartheid welfare 
framework as articulated in the White Paper, 1997) was liberally sprinkled through agency materials; for example, in 2004/5 Agency 4 stated in its Annual Report:

"We prioritise having children with the family and in the community context and follow the community based family preservation model ... There has been a restoration of an ethics of care ... We have an integrated poverty eradication strategy: we assist with the development of parental skills, find employment, and improve relationships in family... We have programmes which prevent and respond to all forms of violence and empower women and children and effective strategies to deal with perpetrators... By taking care of their physical and emotional needs, we create a basis for motivation to release each recipient's full potential. We try to improve the recipient's self-esteem, create a feeling of competency which should secure their future ... The participation consultancy process forms part of our functioning, we find it vital to make the recipient part of the process in establishing and addressing their own specific needs and solutions."

In 2005/6 Isolabantwana, a programme promoted by the National Council, was initiated. Agency 5, based in a village, came under the auspices of the National Council as a home-based programme in 2004, maturing into Asibavikele (formal national home-based care programme) in 2005.

The final agency reviewed, Agency 6, sprung up as a youth-focused agency in a township in 1997, applying for affiliation to the National Council in 2002. In 2005 a social work post was created to complement the responsibilities of the youth workers employed.

The histories provided above offer some clues as to the nature of child protection services. The texts reviewed suggest that the fluctuations in demand for particular services and by particular groups of people were affected by external factors. The following table offers a summary of the trends as identified by the author in the agency materials, using the language in the documents. The lack of funds and suitably qualified social workers was an ongoing issue.

TABLE 1

FLUCTUATIONS IN DEMAND AND RESOURCES

\begin{tabular}{|c|c|c|}
\hline Decreases & Years & Increases \\
\hline $\begin{array}{l}\text { Revenue } \\
\text { Housing }\end{array}$ & 1948 & $\begin{array}{l}\text { Costs of living } \\
\text { Activity/case loads } \\
\text { "Non-European" work } \\
\text { Worker anxiety } \\
\text { Interest in establishing crèches } \\
\text { General symptoms of family discord, divorce and } \\
\text { drunkenness } \\
\text { Applications for children for institutions or day } \\
\text { nursery care } \\
\text { Congestion at Native Commissioner's office }\end{array}$ \\
\hline
\end{tabular}




\begin{tabular}{|c|c|c|}
\hline Decreases & Years & Increases \\
\hline $\begin{array}{l}\text { Number of social science graduates } \\
\text { Funds }\end{array}$ & 1950 & $\begin{array}{l}\text { Crèches waiting lists } \\
\text { Caseloads } \\
\text { Costs of living } \\
\text { Family strain due to financial stressors } \\
\text { Troubled times } \\
\text { Population }\end{array}$ \\
\hline $\begin{array}{l}\text { Numbers of senior social workers } \\
\text { Funds }\end{array}$ & 1960 & $\begin{array}{l}\text { Personnel problems } \\
\text { Staff turnover }\end{array}$ \\
\hline & 1970 & Abandoned babies \\
\hline $\begin{array}{l}\text { Number of social workers } \\
\text { Number of foster homes } \\
\text { Economy (downturn) }\end{array}$ & 1980 & $\begin{array}{l}\text { Relatives applying for grants } \\
\text { Unmarried mothers; single parents; unmarried } \\
\text { mothers keeping children } \\
\text { Divorce } \\
\text { Step-parent adoptions } \\
\text { "Indians" moving to "white" areas } \\
\text { Political turmoil }\end{array}$ \\
\hline & 1985 & $\begin{array}{l}\text { Unemployment } \\
\text { Instability } \\
\text { Demand for services } \\
\text { Unregulated private adoptions }\end{array}$ \\
\hline $\begin{array}{l}\text { Economy } \\
\text { Housing } \\
\text { Adoptive homes } \\
\text { Staff }\end{array}$ & 1990 & $\begin{array}{l}\text { Sexual abuse } \\
\text { AIDS; children with medical dispositions; babies in } \\
\text { care dying of AIDS } \\
\text { Neglect } \\
\text { Material need } \\
\text { Abandonment } \\
\text { Unemployment } \\
\text { Workload } \\
\text { Social problems } \\
\text { Reports from inner city }\end{array}$ \\
\hline Corporate funding & 1995 & $\begin{array}{l}\text { Government attention to street children and homeless } \\
\text { children } \\
\text { Media coverage } \\
\text { Child abuse reports } \\
\text { Child rape } \\
\text { Traumatised personnel } \\
\text { Relationship problems } \\
\text { Uncontrollable teens (Satanism and peer pressure) } \\
\text { Material problems } \\
\text { Adoption challenges } \\
\text { HIV and AIDS }\end{array}$ \\
\hline Private sector funding & 2000 & $\begin{array}{l}\text { Babies with FAS, TB and HIV and AIDS } \\
\text { Child-headed households } \\
\text { Dying babies; funerals } \\
\text { Unmarried mothers keeping babies } \\
\text { Children in care with behavioural problems } \\
\text { Refugee children; undocumented children and adults } \\
\text { Sexual abuse }\end{array}$ \\
\hline
\end{tabular}




\begin{tabular}{|l|l|l|}
\hline Decreases & Years & Increases \\
\hline & & Abandonment; neglect \\
& & "White" special needs babies \\
& Delays in long-term planning \\
& Statutory and complex cases \\
& Demand for tertiary services \\
& Poor and destitute persons \\
& Unregulated facilities \\
& & Acceptance of HIV+ children \\
& Trained foster parents \\
\hline \multirow{2}{*}{2005} & Material need \\
& & Neglect circumstantial \\
& Drug abuse \\
& Child-headed households \\
& Abandoned babies \\
& Orphans \\
& & Children with FAS \\
\hline
\end{tabular}

In considering the above histories, the societal developments such as economic swings, the HIV and AIDS epidemic, and influx of refugees clearly impacted on service delivery in the agencies reviewed. A further facet of South African child welfare that emerges is the early stress on health care, directed at improving the health status of children and their families. Today there is once again a concern with the distribution of food, or as currently expressed "nutrition", evident in the handing out of food parcels, participating in soup kitchens, and making meals available to children through crèches and shelters. Furthermore, the requirement to address HIV and AIDS once more inserts a health focus back into child welfare. What is most evident from the timeline is that, firstly, securing sufficient funding has been a perennial concern for South African child welfare and, secondly, that the demand for services has consistently increased, groups of vulnerable children being added over time.

\section{DISCUSSION}

Despite a small number of agencies being examined, the history of the National Council and of the six agencies highlights certain themes.

Firstly, the accounts speak to the important role of government policies in shaping the trajectory of South African child welfare agencies. This confirms the broader analyses referred to in the literature. The early influences derived from colonialism, echoing developments in the United Kingdom and the United States. The foundation of racebased service delivery was formed in this time, formalised by the introduction of apartheid. The disparity created through racial discrimination is highlighted in the fact that the agencies now located in cities chose to render services primarily to "whites" and submitted to a segregation agenda. These organisations were able to establish themselves and, although regularly buffeted by the limited resources directed towards the welfare sector while having to deal with ongoing and increasing demand, survived apartheid. While documentation is not in all cases extensive, the histories of the agencies 
can be tracked. The experience of the two township and one village agencies stands in strong contrast. While Agency 3 has offered crèche services for many years, its social work services to vulnerable children are embryonic and the historical administrative records are almost entirely non-existent. Agencies 5 and 6 are young organisations and the palette of services is limited. In all agencies there is evidence of the influence of the post-apartheid policy of developmental social welfare, even if, as argued elsewhere (Schmid, 2008), in the case of the agencies reviewed this has not always translated from rhetoric into practice.

A second related theme highlighted by the narratives is the tension that the demand for racial segregation and discrimination created in the agencies. This is presented most markedly in the case of the National Council, where the voice of the dissenters (typically "black" persons) is marginal, but nevertheless present. While the Council was not generally responsive to the concerns raised, it did over time shift towards racial representivity in its governance, advocacy and service delivery.

Thirdly, an aspect regarding the first decades of South African child welfare is the emphasis on medical interventions. Although social workers became the prime service providers from the 1940s, as noted, the National Council only disbanded the Professional Health Committee in the mid-1980s. The author was not able to establish what factors prompted the shift from a medical to a social work perspective. The current impact of HIV and AIDS as well as attempts to respond to mass poverty appear to have driven agencies to return to the type of instrumental programming (e.g. the distribution of food parcels) that characterised early South African child welfare efforts, but it has not pushed organisations back into a medical orientation.

The highlighted narratives do suggest that child welfare agencies are capable of adaptation and change. Long-established structures have been able to introduce new aspects to their programming such as abortion counselling, income-generation programmes, service delivery for all forms of violence affecting children, and programmes directed at dealing with HIV and AIDS. Brand new initiatives have emerged in recent years and are being supported by the National Council.

The history of South African child welfare is complex. The above review, from the dominant perspective of service providers, offers one account regarding past developments. This recounting is incomplete, telling only part of the story of the formal child welfare system. For example, the voices of resistance to the apartheid agenda are only briefly illuminated in the narratives of the child welfare agencies reviewed. These accounts also do not include the many stories of families and communities themselves taking responsibility for the most vulnerable in the absence of a government or professional response. The observation by DeMotigny (1995) that the voice of service recipients is not typically reflected in the narratives by professionals is confirmed in this study.

In the material examined the author found brief references to potential alternative child welfare stories. Two accounts suggest that child protection has not consistently been understood as a formal, primarily tertiary response to dealing with abused, abandoned 
and neglected children. For example, a township project falling under the auspices of Agency 2 began by offering after-school care in 1968/9, but also ballet lessons as it was felt that underprivileged children should also be "introduced to a world of enchantment". More recently, in 2006, while Agency 6 was offering a palette of services that did include formal child protection interventions, it ran an after-school care programme that offered "drama, music, dance and soccer". The promotion of crèches as a child welfare response also supports the view of a broader understanding of child welfare. In 1952 Agency 1 provided accommodation to children and families after a tornado ravaged a city area, while a more recent National Council document for the Limpopo province noted that workers had to intervene after floods had devastated rural areas, though how they did so was not stated. There is in these two experiences a discourse about how child welfare agencies should respond to natural disasters. Further hidden stories are alluded to in the next examples. In 2005 Agency 5's workers dealt not only with mortalities as a result of HIV and AIDS, but also with children being killed in ritual murders. These social workers must have made decisions about how to connect official discourses around child abuse with marginalised 'traditional' discourses and determined which parts of indigenous narratives they supported or rejected. A report by Agency 1 in 2006/7 notes that when police conducted raids, they removed the donated blankets the street girls were using. However, how the social workers dealt with this problem is not reported. This encapsulates an untold story of how social workers respond to repression in their work. There seems to be another hidden story regarding intersectoral work in Agency 2's alarming report in 2003/4 regarding a service delivery area where 45 soup kitchens were operating independently of each other. What other drivers influence the dominant child welfare discourse? For example, why did a concern regarding surrogate parenting appear in the National Council newsletter in 1990, and what makes this apparently less relevant today? The brief stories referenced in this paragraph serve as a reminder of the multi-textured nature of any discourse, of the visible and hidden elements. These historical instances point to broader questions about child welfare discourse and how it is shaped and maintained.

\section{CONCLUSION}

The narratives above confirm and add to what is already on the historical record regarding child welfare. While the dominant story pertains to how child welfare developed in response to colonial and apartheid directives, and as the author has previously argued (Schmid, 2010), affirms an overwhelming child protection discourse, it also hints at alternative, less visible stories. First, the extent to which a health agenda drove early child welfare intervention is of interest. A developmental child welfare orientation prompted an inter-sectoral approach. It may be useful to examine the early history for lessons in how the medical and social welfare aspects of child welfare might be usefully integrated. Second, many of the initial interventions appear to have been instrumental in nature. Such responses seemed to be re-emerging towards the end of the period studied. The extent to which this is a useful development should be interrogated against the early child welfare history. A third strong theme that emerged is the resistance to the imposition of apartheid policies within sections of the National Council. 
The author (Schmid, 2008b) established in her doctoral study that, with the continuation of the child protection discourse into a post-apartheid era, one could not clearly delineate two different child welfare epochs before and after the formal ending of apartheid in 1994. This is suggestive of great complexity. The internal dissent suggests that there have always been voices within child welfare that have spoken for children's rights as a first priority. The isolated instances of alternative practice alluded to above further reinforce that child welfare services have at times been delivered in nuanced ways. Finally, another marginal story is the way in which child welfare services have changed in response to changing family forms and the societal acceptance of, for example, abortion. These minor stories suggest that the child welfare field does have the capacity to change and ultimately to align services more closely with the needs of South Africa's vulnerable children and families.

As digital archiving becomes increasingly prevalent, it is important that the history contained in the many written documents that still exist (such as Jo'burg Child Welfare's almost complete set of Annual Reports) and the stories of seasoned child welfare leaders of all backgrounds be captured. Both dominant stories as well as the hidden stories need to be written up. Much is left to tell and this author hopes that social work historians will be prompted by this article to report the many untold stories. This remains critical in that an appreciation of our historical context continues to help us unravel the meaning of our current child welfare system.

\section{REFERENCES}

ALLSOPP, M. 2005. Tracing our history: contextualising child and youth care within a South African reality. Child and Youth Care, 23(7):22-27.

ALVESSON, M. \& SKOLDBERG, K. 2000. Reflexive methodology. Thousand Oaks, CA: Sage Publications.

BADROODIEN, A. 2001. A history of the Ottery School of Industries in Cape Town: issues of race, welfare and social order in the period of 1937 to 1968. Bellville: University of Western Cape. (Doctoral dissertation)

BEUKES, K. \& GANNON, B. 1999. A history of child and youth care. An orientation to child and youth care $\left(2^{\text {nd }}\right.$ ed). Cape Town: National Association of Child Care Workers.

CAMERON, G., FREYMOND, N., CORNFIELD, D., \& PALMER, S. 2001. Positive possibilities for child and family welfare: Options for expanding the AngloAmerican child protection paradigm. Department of Social Work: Wilfrid Laurier University.

CARNIOL, B. 2000. Case Critical ( $4^{\text {th }}$ ed). Toronto: Between the Lines.

CHILD WELFARE SOUTH AFRICA (CWSA) 2005. Newsletter (May). Johannesburg. DE MOTIGNY, G. 1995. Social working: an ethnography for front line practice. Toronto: University of Toronto Press.

FOUCAULT, M. 1972. The archaeology of knowledge. New York: Pantheon Books. 
308

LOFFELL, J. 2000. Truth and the social services. Social Work/Maatskaplike Werk, 36(1):53-68.

LONNE, B., PARTON, N., THOMSON, J. \& HARRIES, M. 2009. Reforming Child Protection. Oxon, United Kingdom: Routledge.

MAGUBANE, Z. 2002. Globalization and the South African transformation: the impact on social policy. Africa Today, 49(4):89-110.

McKENDRICK, B. 2001. The promise of social work: directions for the future. Social Work/Maatskaplike Werk, 37(2):105-111.

PATEL, L. 2005. Social welfare and social development in South Africa. South Africa: Oxford University Press.

PATEL, L., SCHMID, J. \& HOCHFELD, T. 2012. Transforming social services in South Africa: NPO managers' perspectives. Administration in Social Work, 36:212230. Doi 10.1080/03643107.2011.567321.

SCHMID, J. 2010. A history of the present: uncovering discourses in (South African) Child Welfare. British Journal of Social Work, 40(7):2102-2118. Doi 10.1093/bjsw/bcp124.

SCHMID, J. 2008a. Using governmentality to develop an understanding of postapartheid child welfare. Social Work Practitioner-Researcher, 20(2):212-232.

SCHMID, J. 2008b. The story of South African Child Welfare: a history of the present. Canada: Wilfrid Laurier University. (Doctoral Dissertation)

SCORDILLIS, M. \& BECKER, L. 2005. Post-adoption reunion: a South African perspective. Social Work/Maatskaplike Werk, 41(1):54-67.

SEPTEMBER, R. 2006. A review of child protection services in South Africa: state of the art policies in need of implementation. Social Work/Maatskaplike Werk, 42(1):5467.

SIMONS, H. \& SIMONS, R. 1969. Class and colour in South Africa 1850-1950. South Africa: Penguin Publishers. [Online] Available: www.anc.org.za/books/ccsao. html. [Retrieved: 05/03/2008].

TABACK, R. 2001. Policy Implementation in the Gauteng Department of Welfare and Population Development. Johannesburg: University of Witwatersrand. (Unpublished MA dissertation)

TRUTH AND RECONCILIATION COMMISSION. 1999. Submission from the welfare sector to the Truth and Reconciliation Commission (TRC).

Dr Jeanette Schmid, Research Fellow, Centre for Social Development in Africa, University of Johannesburg, Johannesburg, South Africa. 